\title{
Using Writing Templates as Materials to Improve Writing Skills in EFL Classes: An Experimental Study
}

\section{Yazma Şablonlarının Orta Düzey Dil Öğrencilerinin Yazma Becerilerini Geliştirmede Kullanımı: Deneysel Bir Çalışma}

\author{
Ahmet Selçuk AKDEMİ**, Aysel EYERCI***
}

\begin{abstract}
In this study it was aimed at revealing the findings of an experimental study in which writing templates were used as writing materials to improve writing skills in intermediate (B1) EFL classes as well as reviewing the concepts writing skills, second language writing and writing templates. The study was conducted with 50 students, aged 20-23, of a public university in Turkey. In Writing and Speaking in English II class writing templates were used as writing materials during 12 weeks. The students were asked to fulfil tasks asking them to use some basic writing types for B1 level such as formal and informal letter writing, CV writing, writing business e-mails etc. before and after the study. It was concluded that writing templates can be used as writing materials to improve intermediate (B1) EFL classes.

Keywords: Writing, writing templates, L2 writing.
\end{abstract}

Öz: Bu çalışmanın amacı yabancı dil olarak İngilizce öğrenen öğrencilerin yazma becerilerini geliştirmede yazma şablonlarının kullanımının etkililiğini deneysel bir çalışma aracılığıyla belirlemektir. Çalışma, Türkiye'deki bir devlet üniversitesinde eğitim görmekte olan 20-23 yaşları arasındaki 50 öğrencinin katılımıyla gerçekleştirilmiştir. İngilizce Yazma ve Konuşma II dersinde 12 hafta boyunca yazma şablonları kullanılmıştır. Öğrencilerden, çalışma öncesinde ve sonrasında B1 düzeyinde resmi veya özel mektup, özgeçmiş, iş mektubu gibi dokümanlar hazırlamaları istenmiştir. Çalışmanın sonucunda yazma şablonlarının B1 düzeyindeki öğrencilerin yazma becerilerini geliştirmede kullanılabileceği belirlenmiştir.

Anahtar Kelimeler: Yazma becerisi, yazma şablonları, yabancı dilde yazma becerisi.

\section{Introduction}

As being one of the crucial productive skills, writing in a second language has a key role in individuals' professional lives regarding the challenges of contemporary professional and academic life. It is possible to say that writing must be developed as a skill or a habit but sometimes it may be too late for second language learners. It is undoubtedly a great challenge to select the best approaches, methods and techniques to be used in EFL classes.

Writing teachers have a dual challenge: Not only must they help the most reticent and timid writers overcome a potentially crippling writing phobia, but they must also instil in their students the confidence needed to translate their thoughts into correct and acceptable English. Even though the writing product is an expression of one's individuality and personality, it is important to remember that writing is also an endeavour, a way of communicating with others, inform them, persuading them, and debating with them.

As a technique, using writing templates in EFL writing classes is suggested to be an effective way of teaching how to write. In the simplest way, templates can be defined as models. Specifically, writing templates are skeletal syntactic frameworks-parts of sentences or paragraphs with blanks to fill in with words of learner's choice.

In this study it was aimed at revealing the findings of an experimental study in which writing templates were used as writing materials to improve writing skills in intermediate (B1)

\footnotetext{
*Asst. Prof. Dr., Ağrı İbrahim Çeçen University, Faculty of Science and Letters, Ağrı -Turkey, e-mail: aselcukakdemir@gmail.com (Corresponding Author)

**Lecturer, Atatürk University, School of Foreign Languages, Erzurum-Turkey, e-mail: ayselcatal@atauni.edu.tr
} 
EFL classes as well as reviewing the concepts "Writing Skills", "Second Language Writing" and "Writing Templates".

Since templates allow for creative expressions while giving a beginner writer the tools to write a successful paper, the question of whether they have that remarkable effect on writing process rose in the researchers' mind. They aimed to examine these templates efficiency and reveal their contribution into writing in EFL setting.

Writing, a challenging area both for language learners and teachers, has been the main focus of a wide range of studies, however, the related literature lacks the studies referring writing templates despite their frequent usage in almost every writing related material, which substantially makes the current study remarkable. This study is also marked in terms of being the first experimental study mentioning about the writing templates and their application in EFL settings although some blog writings and comments, suggestions, tips for EFL teachers on using them as effective materials can be encountered on various websites.

\section{Theoretical Framework of The Study}

\section{Second language writing}

About distinguishing writing from other language skills and identifying the place of writing skill in language learning, some fundamental aspects of writing, approaches to writing skill and to the methodology of developing writing skill need to be addressed. The notion of writing has been defined and identified by various scholars in view of various approaches (Kroll, 2001; Lightbown \& Spada, 2006; McDonough \& Shaw, 2003; Nation, 2009). However, whichever meaning and understanding we adopt, we need to know about writing, as well as writing itself. The word 'writing' may be used to mean orthography, written discourse, the act of writing, or literature (Silva \& Matsuda, 2002, p. 251).

Also, the literature on writing skill provides a wide range of practices and empirical studies. These are mostly focused on developing writing or assessment procedures (Crusan, Plakans \& Gebril, 2016; Hunter, Mayenga \& Gambell, 2006; Ruiz-Funes, 2015; Telçeker \& Akcan, 2010; Yoon, 2016). Several studies indicated innovative ways of developing writing. Web-based collaborative writing (Bikowski \& Vithanage, 2016), narrative-centered digital learning environment (Pruden, Kerkhoff, Spires \& Lester, 2016), portfolio assessment (Lam, 2013; Romova \& Andrew, 2011), tutor mediation (Shrestha \& Coffin, 2012), self-monitoring and reflexive assessment (Hawe \& Dickson, 2014; Ryan, 2014), writing and its relationship with linguistic variables (Guanghui \& Qiufang, 1999), teacher and peer corrective feedback (Aghajanloo, Mobini \& Khosravi, 2016; Alizadeh Salteh, Yağız \& Sadeghi, 2013; Cunningham, 2015; Elola \& Oskoz, 2016; Fordham, 2015) have been among recent studies reflecting the research trends in the vast literature of writing.

Any discussion of L2 students' writing needs must first take into account the wide diversity among L2 learners as distinct groups each with its own uses of, and needs for, writing. Students in EFL contexts will need English writing skills ranging from simple paragraph writing and summary skills to the ability to write essays and professional articles.

In ESL contexts the range of written needs is equally diverse, although the needs will, for the most part, be more academically oriented. There are a number of factors relating to the theory and practice of writing instruction in second language which go well beyond the concerns and issues central to writing practices in L1 contexts.

\section{Writing Templates as writing materials}

Most simply stated, templates are models. In other words, they are tools to help you with all of your different kinds of writing tasks. More specifically, writing templates are skeletal syntactic frameworks-parts of sentences or paragraphs with blanks to fill in words of your choice. King (2007) considers templates valuable because of the fact that they are highly beneficial for the reader to understand better what you are trying to say. They help you, the writer, with 
organization, and they help you to develop the kinds of sentence, paragraph, and paper structure that strong writers display.

The use of writing templates is one of the best ways to cope with the difficulties while writing in a professional manner (Sumerset, 2008). According to Sumerset (2008) writing process starts with a blank document, then the task gets harder when students try to find the starting point. Whether it is a short informal note or a professional correspondence text, any writing is an arduous task in the first few lines. As Sumerset (2008) indicates, writing templates help overcome the initial frustration caused by lack of advanced competences in writing skill. Apart from their time-saving feature, writing templates provide a basic outline and help students fulfil various writing tasks with fewer mistakes. Some of the most commonly used writing templates are:

- Resumes

- Reports

- Business Letter Writing

- Legal Writing

- Screenwriting

- Business Writing Templates

- Medical Writing Templates

- Scriptwriting Templates

- Everyday Writing Templates.

It is also possible to find templates to write reports, term papers, scholarly papers or even college admissions essays. The literature on the development and use of writing templates is rather restricted. Supatranont (2012) suggested using writing templates for research article abstracts. Using a corpus-based method, she developed a writing template which can be used by academics to write research article abstracts.

\section{Teaching writing at independent levels (B1-B2)}

Besides its roots date back to 1971, the Common European Framework of reference for language learning, teaching and assessment (CEF) started to provide a common basis for the elaboration of language syllabuses, curriculum guidelines, examinations, textbooks, etc. across Europe (Council of Europe, 2001).

One of the main objectives of CEF is to describe thoroughly what language learners have to learn to do in order to use a language for communication and what knowledge and skills they have to develop so as to be able to act effectively. As well as many radical and effective changes CEF, also aimed to describe the levels of proficiency required by existing standards, tests and examinations so as to facilitate comparisons between different systems of qualifications. For this purpose the Descriptive Scheme and the Common Reference Levels have been developed. These reference levels is composed of six broad levels, which are respectively higher and lower interpretations of the classic division into basic, intermediate and advanced.
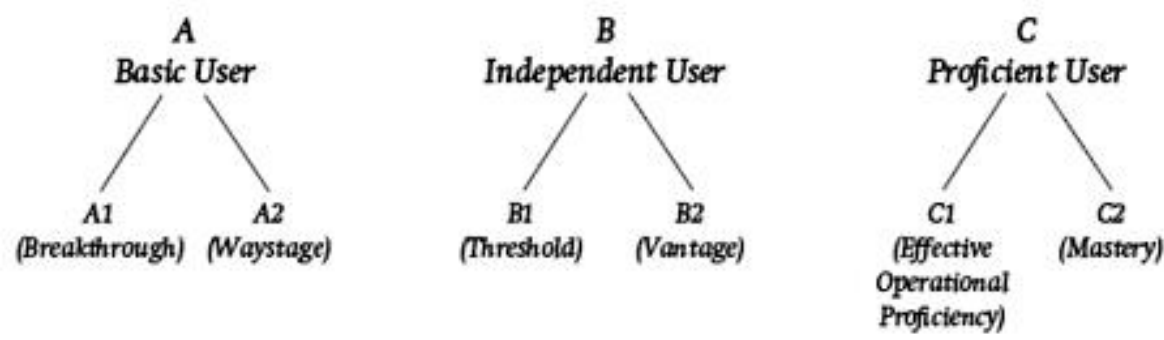

This study aimed at revealing the findings of an experimental study in which writing templates were used as writing materials to improve writing skills in intermediate (B1) EFL 
classes. According to CEF Reference Levels a language learner in B1 level is supposed to achieve the following items in writing skills.

I can write simple connected text on topics which are familiar or of personal interest. I can write personal letters describing experiences and impressions (Self-Assessment Grid)

Can understand the main points of clear standard input on familiar matters regularly encountered in work, school, leisure, etc.

Can deal with most situations likely to arise whilst travelling in an area where the language is spoken.

Can produce simple connected text on topics which are familiar or of personal interest. Can describe experiences and events, dreams, hopes and ambitions and briefly give reasons and explanations for opinions and plans (Council of Europe, 2001).

The proficiency level of a B1 learner in writing and global scale is described as mentioned above when the CEF taken into consideration as a reference. On the other hand it will be beneficial to review how the intermediate level is characterized in terms of writing skills.

Grabe and Kaplan (1996) point out that as the students get more experienced in writing they move into educational contexts with more demanding learning tasks, writing instruction takes on new dimensions. Basic fluencies and abilities remain important components of writing instruction, yet additional abilities which must be developed and many resources for writing which must be invoked are included in intermediate level of writing instruction. Grabe and Kaplan (1996) describe the intermediate level student of writing as follows in detailed:

"The intermediate student is one who is able to write on a basic level and now must use writing to learn a wide range of other academic information; someone who uses writing to learn about history, science, literature, social studies, mathematics, arts, and foreign languages. Students at this level must learn how to read from multiple sources and write from these sources. At the same time, intermediate students are continually gaining control over additionally vocabulary and more complex sentence structure while also gaining a greater degree of stylistic maturity, a reflection of a growing sense of purpose and audience in their writing".

Intermediate writers could be classified in two major groups to improve their writing for academic purposes. For the student in the public school context, the intermediate writer is seen as the secondary school student, roughly grades 6-11 (ages 12-17). These students presumably have mastered the basic skills for composing simple messages and mechanics of writing. The second well-defined group of intermediate students is the international ESL students who seek to enter an English speaking tertiary- level academic institution but has only an intermediate level of English language skills. These students have typically mastered the mechanics of writing in English, and have developed basic fluency in writing through practice. A third possible group, adult literacy students, often do not beyond basic literary abilities in their class work. For this reason they do not represent a major group of students requiring intermediatelevel writing instruction.

\section{Methods and procedures}

\section{Method}

The researchers gathered data about the writing templates and prepared a syllabus and course materials that would fit the course Writing and Speaking in English II. The pursuance of the current study, which depends on writing approach, was also designed by the researchers.

\section{Participants}

The participants of the study, who were randomly picked on, were the two groups of students, aged between 20 and 23, enrolling in Writing and Speaking in English II, of International Relations Department at Atatürk University. 


\section{Data Collection Tools}

The students were asked to fulfil tasks asking them to use some basic writing types for B1 level such as formal and informal letter writing, CV writing, writing business e-mails etc. before and after the study. A writing Pre-test was administered to both groups in order to test their proficiency level in writing, which indicated no statistically significant difference in terms of their mean scores. These writing templates were used as writing materials for 12 weeks. Both groups were asked to get the writing post-test, which was exactly the same as the pre-test at the end of 12-week-educational season. After comparing the mean scores the final examinations, the researchers graded the all the tests and used t-test so as to analyse them.

\section{Data Analysis}

The researchers of the study preferred to implement an experimental design, which divides the participants randomly into two groups, the experimental group and the control group, and then introduce a change to the experimental group and not the control group. The change of this study was the using writing templates in writing courses for the experiment group rather than the control one. The control group, on the other hand, had a traditional teaching. A writing quiz (Writing Quiz 1) was administered to both groups during the mid-term examination and the researchers compared the mean scores of them. The same procedure was repeated twice: one in the middle of treatment and the second in the final examination via another writing quiz (Writing Quiz 2 and Writing Quiz 3), whose mean scores were compared as well. Both groups were asked to get the writing post-test, which was exactly the same as the pre-test at the end of 12-week-educational season. After comparing the mean scores the final examinations, the researchers graded the all the tests and used t-test so as to analyse them. The interrater reliability of study was also ensured, which assured that the generated results meet the accepted criteria defining reliability, by quantitatively defining the degree of agreement between two or more observers. Before this study was initiated, a group of students was requested to write on a topic and those papers helped the researchers measure the reliability of rating. In the end, the raters were fairly consistent in their overall ratings since they used the holistic scoring rubrics and ESL Composition Criterion in order to be as objective as possible.

\section{Analysis and findings}

This part is devoted to the presentation of quantitative analyses and findings of the study. Pretest and post-test results of the groups are shown in Table 1.

Table 1 Mean and Standard Deviations (SD) of the Experiment and the Control Groups on the Pre-test and post-test

\begin{tabular}{lll}
\hline Group of students & Pre-test mean (SD) & Post-test mean (SD) \\
\hline \multirow{2}{*}{ Experiment group } & 64.74 & 66.92 \\
& $(7.07)$ & $(8.96)$ \\
Control group & 66.96 & 63.04 \\
& $(8.34)$ & $(7.14)$ \\
\hline
\end{tabular}

The mean scores of pre-test for the experiment group and the control group are respectively 64.74 and 66.96. As it can be seen from Table 1, the Standard Deviations (SD) are 7.07 for the experiment group and 8.34 for the control group. The mean scores of post-test for the experiment group and the control group are respectively 66.92 and 63.04. As it can be seen from the table, the Standard Deviations (SD) for the groups are 8.96 for the experiment group and 7.14 for the control group.

Based on writing quiz applications in three phases, the development of writing performances of the groups are shown in Table 2. 
Table 2 Mean and Standard Deviations (SD) of the Experiment and Control Groups on the Writing Achievement Tests (Writing Quiz 1, Quiz 2 and Quiz 3)

\begin{tabular}{lllll}
\hline Group Students & $\begin{array}{l}\text { Writing Quiz } \\
\text { Mean (SD) }\end{array}$ & $\begin{array}{l}\text { Writing Quiz } \\
\text { Mean (SD) }\end{array}$ & $\begin{array}{l}\text { Writing Quiz 3 Mean } \\
(\mathrm{SD})\end{array}$ \\
\hline \multirow{2}{*}{ Experiment Group } & 69.38 & 70.27 & 72.89 \\
& $(8.20)$ & $(9.91)$ & $(8.53)$ \\
Control Group & 67.97 & 65.72 & 66.54 \\
& $(5.96)$ & $(7.20)$ & $(7.87)$ \\
\hline
\end{tabular}

Table 2 shows that the mean scores of Writing Quiz 1 are 69.38 and 67.97 for the experiment group and the control group respectively. The Standard Deviations of the groups are 8.20 and 5.96 respectively. For Writing Quiz 2, the mean score of the experiment group is 70.27 while it is 65.72 for the control group. The Standard Deviation of the experiment group is found 9.91 while it is found 7.20 for the control group. The mean scores of Writing Quiz 3 are 72.89 and 66.54 for the experiment group and the control group respectively. The Standard Deviations of the groups are 8.53 and 7.87 respectively.

The differences between the writing quiz scores as well as pre-test and post-test results regarding t-test scores and significance levels are shown in Table 3.

Table 3 Compared Means: Independent-Sample t-test (of the Experiment and Control Groups)

\begin{tabular}{llll}
\hline Scores & Mean Difference & t-test & Significant \\
\hline Pre-test & -2.22 & -1.12 & 0.134 \\
Writing Quiz 1 & 1.42 & 0.86 & 0.197 \\
Writing Quiz 2 & 4.55 & 2.30 & $0.012^{*}$ \\
Writing Quiz 3 & 6.17 & 3.10 & $0.009^{*}$ \\
Post-test & 3.88 & 2.08 & $0.021^{*}$ \\
\hline
\end{tabular}

$* \mathrm{p}<0.05$

Table 3 illustrates that t-test analysis indicated no statistically significant difference despite the differences of the mean scores on the Pre-test between the experiment group (64.74) and the control group (66.96). This reveals that a difference is not observed between the performances of both groups. From this data it is inferred that the proficiency levels of both groups was not statistically different at the beginning of the research.

The results of the Writing Quiz 1 show that the experiment group outperformed the control group, as the mean scores of them reveal that the mean score of the experiment group (69.38), and mean score of the control group (67.97). Nevertheless, a significant difference is not observed when analysing the t-test results on Writing Quiz $1, t=0.86$. This data indicates that the treatment of the writing templates as a technique did not help the students of the experiment group increase their performance in their writing ability according to the results of Writing Quiz 1.

The performance of the experiment group, however, increased as the writing treatment progressed in time according to the results of Writing Quiz 2, Writing Quiz 3 and the Post-test. While the mean score of the control group from Writing Quiz 2 was 65.72 and 66.54 for Writing Quiz 3; that of the experiment group was 70.27 for Writing Quiz 2 and 72.89 for Writing Quiz 3. Also the mean score of the control group from Post-test was 63.04 and that of the experiment group was 66.92. And finally the analyses of t-tests affirmed the statistically 
significant difference of the two groups' performance: Writing Quiz 2, 2.30; Writing Quiz 3, 3.10 and on the Post-test, 2.08; $(\mathrm{p}<0.05)$.

All these analyses conclude that the experiment group outperformed the control group in their writing ability as well as pointing out that the students selected as the experiment group and had the treatment gained the ability to write.

\section{Conclusion}

The findings of the study reveal that teaching with writing templates creates higher mean scores in writing tests as well as in post-test. Those students in control group, who were taught with traditional teaching techniques, gained lower scores compared to experiment group. Undoubtedly, the main reason of the difference between the two groups is the use of writing templates to teach writing. Mechanics, language structures, grammar and feedback are among the unique characteristics of the treatment conducted in the current study. As the grammar and structure recedes, students have the opportunity to focus on the message they would like to convey. Feedback activities, in which teacher has a role of coaching students' writings, students can write and rewrite to reach the final draft. The effect of this kind of feedback can be seen through the scores of Writing Quiz 2, Writing Quiz 3 and the post-test. Current study shows that the difference between the two groups is statistically significant only after a process of treatment. This is an apparent evidence for the need of feedback.

All in all, main findings of the study show that the use writing templates can be a vital tool for writing classes who suffer from the deficiencies of traditional teaching methods. It should be noted that both the concept itself and the classroom applications of writing templates are relatively novel. More empirical data is needed to validate the positive effect of using writing templates to improve writing in various classroom settings.

\section{References}

Aghajanloo, K., Mobini, F., \& Khosravi, F. (2016). The effect of teachers' written corrective feedback (WCF) types on intermediate EFL learners' writing performance. Advances in Language and Literary Studies, 7(3), 28-37.

Alizadeh Salteh, M., Yağız, O., \& Sadeghi, K. (2013). EFL teachers' reconstruction of studentwriters' intentions in erroneous sentences: The role of context. Issues in Language Teaching, 2(1), 27-54.

Bikowski, D., \& Vithanage, R. (2016). Effects of web-based collaborative writing on individual L2 writing development. Language Learning \& Technology, 20(1), 79-99. Retrieved from http://lit.msu.edu/issues/february2016/bikowskivithanage.pdf

Council of Europe. (2001). Common European Framework of Reference for Languages: Learning, teaching, assessment. Cambridge: Cambridge University Press.

Crusan, D., Plakans, L. M., \& Gebril, A. (2016). Writing assessment literacy: Surveying second language teachers' knowledge, beliefs, and practices. Assessing Writing, 28, 43-56.

Cunningham, M. (2015). Using audio screencast for feedback on short written essays. Unpublished doctoral dissertation, Southern Illinois University at Carbondale.

Elola, I., \& Oskoz, A. (2016), Supporting second language writing using multimodal feedback. Foreign Language Annals, 49, 58-74. doi:10.1111/flan.12183.

Fordham, S. K. (2015). Teacher and peer written feedback in the ESL composition classroom: Appropriation, stance, and authorship. Unpublished doctoral dissertation, University of Arizona.

Grabe, W., \& Kaplan, R. B. (1996). Theory and practice of writing: An applied linguistic perspective. London and New York: Longman.

Guanghui, M., \& Qiufang W. (1999). The relationship of L2 learners' linguistic variables to L2 writing ability. Foreign Language Teaching and Research, 4, 69-84.

Hawe, E. M., \& Dixon, H. R. (2014). Building students' evaluative and productive expertise in the writing classroom. Assessing Writing, 19, 66-79. 
Hunter, D., Mayenga, C., \& Gambell, T. (2006). Classroom assessment tools and uses: Canadian English teachers' practices for writing. Assessing Writing, 11, 42-65.

King, K.B. (2007). The writing template book. University of Michigan: USA.

Kroll, B. (1991). Teaching writing in the ESL context. In Ed. M. Celce-Mucia. Teaching English as a second or foreign language. Boston: Heinle \& Heinle.

Lam, R. (2013). Two portfolio systems: EFL students' perceptions of writing ability, text improvement, and feedback. Assessing Writing. 18, 132-153.

Lightbown P.M., \& Spada N. (2006). How languages are learned. Oxford Handbooks for Language Teachers: UK.

McDonough, J., \& Shaw, C. (2003) Materials and methods in ELT. Blackwell Publishing: UK.

Nation I. S. P. (2009). Teaching ESL/EFL reading and writing. Routledge: UK.

Pruden, M., Kerkhoff, S. N., Spires, H. A., \& Lester J. (2016). Enhancing writing achievement through a digital learning environment: Case studies of three struggling adolescent male writers. Reading \& Writing Quarterly, 3, 1-19.

Romova, Z., \& Andrew, M. (2011). Teaching and assessing academic writing via the portfolio: Benefits for learners of English as an additional language. Assessing Writing, 16, 111122.

Ruiz-Funes, M. (2015). Exploring the potential of second/foreign language writing for language learning: The effects of task factors and learner variables. Journal of Second Language Writing, 28, 1-19.

Ryan, M. (2014). Reflexive writers: Re-thinking writing development and assessment in schools. Assessing Writing, 22, 60-74.

Shrestha, P., \& Coffin, C. (2012). Dynamic assessment, tutor mediation and academic writing development. Assessing Writing, 17, 55-70.

Silva, T., \& Matsuda, P. K. (2002). Practising theory in second language writing. West Lafayette, Parlor Press: USA.

Silva, T., \& Matsuda, P. K. (2002). Writing. In N. Schmitt (Eds.), An introduction to Applied Linguistics (pp. 250-266). London: Arnold.

Sumerset, J. (2008, November 25). Writing templates. Can they really help you? Retrieved from http://ezinearticles.com/?Writing-Templates---Can-They-Really-Help You?\&id=1726854

Supatranont, P. (2012). Developing a writing template of research article abstracts: A corpusbased method. Procedia Social and Behavioural Sciences, 66,144-156.

Telçeker, H., \& Akcan, S. (2010). The effect of oral and written teacher feedback on student revisions in a process-oriented EFL writing class. TESL Reporter, 43(1), 31-49.

Yoon, C. (2016). Individual differences in online reference resource consultation: Case studies of Korean ESL graduate writers. Journal of Second Language Writing, 32, 67-80.

\section{Uzun Öz}

\section{Giriş}

İngilizceyi yabancı dil olarak öğrenen öğrencilerin yazma becerilerini geliştirmeleri sağlıklı bir dil gelişimi açısından son derece önemlidir. Alan yazında bu konuda yapılmış pek çok uygulamalı ve kuramsal çalışma yer almaktadır. Bu çalışmalar çoğunlukla yabancı dilde yazma becerisinin çeşitli açılardan değerlendirilmesi, ölçülmesi ve geliştirilmesi için yapılabilecek etkinlikleri ele almaktadır. Ayrıca yazma becerisinde öğrencilerin birbirlerinden ve öğretmenlerinden sınıf içerisinde nasıl yararlanabileceklerini ortaya koyan, etkileşimli değerlendirme yöntemlerine değinen çalışmalar da bulunmaktadır. Yazma becerisini diğer dil becerilerinden ayırmak ve onun kendine özgü niteliklerini belirlemek için yazma becerisinin farklı yönlerden ele alınması gerekmektedir. Yazma becerisine ilişkin yöntemler, yaklaşımlar ve temel kavramlar hem kendi başlarına hem de çeşitli değişkenlerle ilişkili olarak değerlendirilmelidir (Kroll, 2001; Lightbown ve Spada, 2006; McDonough ve Shaw, 2003; 
Nation, 2009). Ancak, hangi tanım veya değerlendirme benimsenirse benimsensin yazmanın temelde nasıl tanımlandığı değişmemektedir. Yazma temel olarak yazım, yazılı söylem, yazma etkinliği veya işi veya yazın ya da diğer bir deyişle edebiyat olarak tanımlanmaktadır (Silva ve Matsuda, 2002).

İlgili alan yazında yazma becerisi konusundaki çalışmalar da son derece çeşitli ve geniştir. İlgili çalışmalar çoğunlukla yazma becerisi geliştirme ve değerlendirme etkinliklerine odaklanmıştır (Crusan, Plakans ve Gebril, 2016; Hunter, Mayenga ve Gambell, 2006; RuizFunes, 2015; Telçeker ve Akcan, 2010; Yoon, 2016). Yazma becerisini geliştirmede yenilikçi çalışmalar çoğunlukla web tabanlı işbirlikçi yazma (Bikowski ve Vithanage, 2016), anlatım merkezli dijital öğrenme ortamları (Pruden, Kerkhoff, Spires ve Lester, 2016), dosya temelli değerlendirme (Lam, 2013; Romova ve Andrew, 2011), danışman odaklı yazma (Shrestha ve Coffin, 2012), öz-izleme ve yansıtmacı değerlendirme (Hawe ve Dickson, 2014; Ryan, 2014), yazma becerisi ve dilbilimsel değişkenlerle ilişkileri (Guanghui ve Qiufang, 1999), öğretmen ve akran merkezli geribildirim ve değerlendirme (Aghajanloo, Mobini ve Khosravi, 2016; Cunningham, 2015; Fordham, 2015) gibi konulara odaklanmıștır. Bununla birlikte, yazma becerisini geliştirmede kullanılabilecek yazma şablonlarıyla ilgili çalışmalar sınırlı sayıdadır (King, 2007; Sumerset, 2008; Supatranont, 2012). Yazma şablonları, özellikle başlangıç ve orta düzeyde yazma becerisinin geliştirilmesinde etkili ve verimli bir biçimde kullanılabilen hazır şablonlardır. Bu şablonlar öğrencilerin yazma becerisinde özellikle ilk adımlarda karşılaştıkları güçlükleri aşmalarında onlara yardımcı olmaktadır. Yazma şablonları en basit ifade ile yazma modelleri olarak tanımlanabilir. Diğer bir deyişle, öğrencilerin kendilerinin seçecekleri kelimelerle, boşlukları olan cümle ve paragrafları dolduracağı temel yapısı oluşturulmuş taslaklardır. Bir teknik olarak bu yazma şablonlarını kullanmanın yazmayı öğretme konusunda etkili bir yöntem olduğu düşünülmüştür.

\section{Yöntem}

İki gruplu deneysel bir araştırma deseniyle gerçekleştirilen bu çalışmada, yazma şablonlarının yabancı dil olarak İngilizce öğrenen başlangıç düzeyindeki öğrencilerin yazma becerilerini geliştirmedeki etkisi araştırılmıştır. Çalışmaya Türkiye'deki bir devlet üniversitesinde eğitim görmekte olan ve yaşları 20 ile 23 arasında değişen 50 öğrenci katılmıştır. Rastgele ayırma yöntemiyle deney ve kontrol grubu olarak iki grup oluşturulmuş ve her iki gruba da ön test uygulanmıştır. Bu öğrencilerin almakta oldukları İngilizce Yazma ve Konuşma II dersinde toplamda on iki hafta boyunca deney grubuna araştırmacı tarafından ilgili kaynaklardan derlenen yazma şablonları kullanılarak eğitim verilmiştir. Kontrol grubunda ise müfredatın öngördüğü olağan yazma eğitimi uygulanmıştır. Katılımcı öğrencilerden, çalışmanın öncesinde ve sonrasında yetkinlik düzeylerine uygun olarak resmi veya özel mektup, özgeçmiş dosyası, iş mektubu gibi çeşitli yazılı dokümanlar hazırlamaları istenmiştir. On iki haftalık uygulama sonunda, deney grubuna verilen eğitimin etkililiğini belirlemek amaciyla yazma etkinliklerinde kullandıkları yazma şablonlarının onların yazma becerileri üzerinde ne gibi etkileri olduğu incelenmiştir. Ön test ve son test ölçümlerinde öğrencilerin ortaya koyduğu yazılı dokümanlar iki araştırmacı tarafindan değerlendirilmiştir. Araştırmacıların değerlendirmeleri arasındaki farkı belirlemek amacıyla bir pilot uygulama yapılmış ve değerlendirme güvenilirliği belirlenmiştir. Ön test ve son test değerleri arasındaki farklı1ıklar SPSS aracılığıyla analiz edilerek araştırmacılar tarafından ilgili alan yazın ışığında değerlendirilmiştir.

\section{Bulgular ve sonuç}

Araştırmada elde edilen veriler analiz edilerek ön test ve son test değerleri deney ve kontrol gruplarının kendi içlerinde ve birbirleri arasındaki fark açısından ele alınmıştır. Ayrıca gruplara uygulanan yazma becerisi testlerinin sonuçları da analiz edilmiştir. Deney grubu ön test ortalama puanı 64.74; kontrol grubu ön test ortalama puanı 66.96 olarak bulunmuştur. Deney grubu standart sapmas1 7.07; kontrol grubu standart sapmas1 8.34 'tür. Deney grubu son test ortalama puanı 66.92; kontrol grubu son test ortalama puanı 63.04 olarak bulunmuştur. Deney grubu standart sapmas1 8.96; kontrol grubu standart sapmas1 7.14'tür. 
Gruplara uygulanan yazma testlerine ilişkin sonuçlar karşılaştırıldığında; birinci testte deney grubunun ortalama puan1 69.38, standart sapmas1 ise 8.20; kontrol grubunun ortalama puan1 67.97 , standart sapmas1 ise 5.96 olarak bulunmuştur. İkinci yazma testinde ise deney grubunun ortalama puan1 70.27, standart sapmas1 ise 9.91; kontrol grubunun ortalama puan1 65.72, standart sapması ise 7.20 olarak bulunmuştur. Üçüncü testte deney grubunun ortalama puan1 72.89 , standart sapmas1 ise 8.53 ; kontrol grubunun ortalama puan1 66.54 , standart sapmas1 ise 7.87 olarak bulunmuştur.

Ön test, son test ve yazma testlerinin puanlarının SPSS aracılığıyla karşılaştırılması sonucunda ön test sonuçlarında iki grup arasında istatistiki olarak anlamlı bir fark $(\mathrm{t}=-1.12)$ bulunmamıştır. Diğer bir deyişle ön test sonuçlarına göre iki grup arasında ciddi bir düzey veya başarı farkı bulunmamaktadır.

Birinci yazma testi sonuçlarına bakıldığında deney grubunun kontrol grubuna göre daha yüksek bir puan ortalamasına sahip olmasına rağmen iki grubun ortalama puanları arasında istatistiki olarak anlamlı bir fark $(\mathrm{t}=0.86)$ bulunmamaktadır. Diğer bir deyişle, yazma şablonlarıyla gerçekleştirilen eğitimin ilk haftalarında gerçekleştirilen bu testte deney grubunun kontrol grubuna göre ciddi bir gelişim göstermediği belirlenmiştir.

Ancak, yazma şablonlarıyla verilen eğitimin gruplar arasında yarattığı fark ikinci ve üçüncü yazma testi ve son test ölçümlerinde ortaya çıkmıştır. İkinci yazma testi sonuçlarına göre iki grubun puanları arasında istatistiki olarak anlamlı bir fark $(\mathrm{t}=2.30)$ bulunmuştur. Üçüncü yazma testi sonuçlarına göre ise iki grubun puanları arasında istatistiki olarak anlamlı bir fark $(\mathrm{t}=3.10)$ bulunmuştur. Ayrıca son test ölçümünde de deney grubuyla kontrol grubu puanları arasında istatistiki olarak anlamlı bir fark $(\mathrm{t}=2.08)$ olduğu belirlenmiştir.

Deneysel çalışmanın istatistiki sonuçlarına dayanılarak yazma şablonlarının kullanımının yabancı dil öğrencilerinin yazma becerilerini geliştirmede etkili bir araç olacağı sonucuna ulaşılmıştır. 